\title{
Quality of Life in The Elderly Viewed from Hope, Friend Support, and Family Support
}

\author{
I Ketut Andika Priastana*, Dwi Prima Hanis Kusumaningtiyas \\ Universitas Triatma Mulya, Indonesia \\ * iketutandikapriastana@gmail.com
}

\begin{abstract}
The elderly are the population group most vulnerable to health problems due to the aging process. The presence of the elderly is often considered negative by the family and society. This often causes disruption to the quality of life of the elderly. Quality of life is a parameter of the success of the elderly in maintaining health conditions. This study aims to determine the quality of life of the elderly in terms of hope, friend support and family support. Authors collected data using a survey method based on a questionnaire which included the variables to be measured, namely the quality of life of the elderly, hope, friend support, and family support. The data analysis technique used in this study was logistic regression. The population in this study is the elderly who live in Banjar Tengah, Negara District, Jembrana Regency, Bali. The sample used in this study was selected using purposive sampling method, with a total sample of 62 people who met the criteria. The results showed that there was a significant effect simultaneously of hope, support from friends, and family support on the quality of life of the elderly because the $p$ value Chi-Square was 0,000 where $<\alpha 0.05$ or the value of Chi-Square Count 70.870> Chi-Square table. 7,815. The logistic regression test results show that the Nagelkerke R Square value is 0.908 and Cox \& Snell R Square is 0.681, which indicates that the ability of the independent variable to explain the dependent variable is 0.908 or $90.8 \%$ and there are $100 \%-90.8 \%=9,2 \%$ other factors outside the model that explain the dependent variable.

This study shows that the quality of life of the elderly can be explained by hope, friend support and family support. The results of the study are expected to provide new knowledge for nurses in providing gerontic nursing services to the elderly by increasing hope, friend support, and family support so that it has an impact on the quality of life of the elderly.
\end{abstract}

Keywords: Quality Of Life, Hope, Friend Support, Family Support, Elderly 


\section{STRADA Jurnal Ilmiah Kesehatan}

DOI: $10.30994 /$ sjik.v9i2.519

ISSN: 2252-3847 (print); 2614-350X (online)

Vol.9 No.2 November 2020 Page.1670-1675

\section{BACKGROUND}

The elderly are the population group most vulnerable to health problems due to the aging process. The presence of the elderly is often considered negative by the family and society. This often causes disruption to the quality of life of the elderly. Quality of life is a parameter of the success of the elderly in maintaining health conditions. A good quality of life will encourage them to be independent, productive and prosperous, thereby increasing their health status (Indrayani \& Ronoatmodjo, 2018).

Hope is an important factor for quality of life (Junovandy, Elvinawanty, \& Marpaung, 2019). Research conducted by Souza and Kamble (2016) found a significant positive relationship between hope and quality of life. Hope encourages someone to have toughness in dealing with situations so that it has a positive impact on the quality of life (Souza \& Kamble, 2016). Besides hope, social factors also have a big impact on a person's quality of life (Fahmi, 2019). Social factors that often affect the elderly are friend or peer support and family support. Friend social support is used as a mediator by the elderly in solving problems so that it affects their quality of life. Elderly assume that their friends feel the same way as themselves so that they are more comfortable in socializing solving problems (Azwan, Herlina, \& Karim, 2015). Likewise with family support, the family is present as the closest support system for the elderly. Elderly have a good quality of life with good family support. Family activities are considered the most valuable time for the elderly, this has a significant impact on the quality of life of the elderly. Family support is able to provide assistance to the elderly to rise from bad conditions (Xu et al., 2019).

\section{METHODS}

Researchers collected data using a survey method based on a questionnaire which included the variables to be measured, namely the quality of life of the elderly, hope, friend support, and family support. The questionnaire used is a questionnaire from the World Health Organization Quality of Life (WHOQOL) - BREF which is replicated from WHO (2004) was used to measure the quality of life of the elderly, The Herth Hope Index questionnaire replicated from Herth (1989) was used to measure hope, the Perceived Social Support From Friends (PSS-Fr) questionnaire which was replicated from Procidano and Heller (1983) to measure friend support, and the Perceived Social Support From Family (PSS-Fa) which was replicated from Procidano and Heller (1983) for measure family support.

The data analysis technique used in this study was logistic regression. The population in this study is the elderly who live in Banjar Tengah, Negara District, Jembrana Regency, Bali. The sample used in this study was selected using purposive sampling method, using the criteria of elderly people who were the sample in this study were elderly who had family and friends or peer groups, as well as cooperative and sample selection was based on the condition that the elderly were able to provide answers on the questionnaire sheet. The number of samples in this study were 62 people.

\section{RESULT}

The research results discussed include instrument testing, respondents, logistic regression testing, and hypothesis testing. The following are the results: 


\section{STRADA Jurnal Ilmiah Kesehatan}

DOI: $10.30994 /$ sjik.v9i2.519

ISSN: 2252-3847 (print); 2614-350X (online)

Vol.9 No.2 November 2020 Page.1670-1675

\section{Instrument Test}

The research instrument test was carried out by testing the validity and reliability of 30 respondents. This test was conducted on all research instruments, namely the World Health Organization Quality of Life (WHOQOL) - BREF Questionnaire, Herth Hope Index, Perceived Social Support from Friends (PSS-Fr), Perceived Social Support from Family (PSS-Fa).

\section{World Health Organization Quality of Life (WHOQOL) - BREF}

After the validity test was carried out, it was found that 26 questions had a value of $r$ count $>$ $\mathrm{r}$ table (0.361), which means that the question item was valid. After being tested for reliability and the Cronbach Alpha results obtained were 0.965 or greater than 0.6 , which means that the question item is reliable.

\section{Herth Hope Index}

After the validity test was carried out, it was found that 12 questions had a value of $r$ count> $r$ table (0.361) which means that the question item was valid. After being tested for reliability and the Cronbach Alpha results obtained were 0.763 or greater than 0.6, which means that the question item was reliable.

\section{Perceived Social Support from Friends (PSS-Fr)}

After the validity test was carried out, it was found that 20 questions had a value of $\mathrm{r}$ count $>$ $\mathrm{r}$ table (0.361), which means that the question item was valid. After being tested for reliability and the Cronbach Alpha results obtained were 0.758 or greater than 0.6 , which means that the question item was reliable.

\section{Perceived Social Support from Family $(P S S-F a)$}

After the validity test was carried out, it was found that 20 questions had a value of $r$ count $>$ $\mathrm{r}$ table (0.361), which means that the question item was valid. After being tested for reliability and the Cronbach Alpha results obtained were 0.752 or greater than 0.6 , which means that the question item was reliable.

\section{Research Respondents}

The number of respondents who met the criteria was 62 respondents. All respondents completed 4 research questionnaires so that they deserve to be included in the research data analysis.

\section{Logistic Regression}

\section{Omnibus Test Results}

Logistic regression uses the Chi-Square value of the difference between -2 Log likelihood before the independent variable enters the model and -2 Log likelihood after the independent variable enters the model. This test is also called the Maximum likelihood test. So that the answer to the hypothesis of the simultaneous effect of the independent variable on the 


\section{STRADA Jurnal Ilmiah Kesehatan}

DOI: $10.30994 /$ sjik.v9i2.519

ISSN: 2252-3847 (print); 2614-350X (online)

Vol.9 No.2 November 2020 Page.1670-1675

dependent variable is to accept $\mathrm{H} 1$ and reject $\mathrm{H} 0$ or which means that there is a simultaneous significant effect of hope, friend support, and family support on the quality of life of the elderly because the $\mathrm{p}$ value of Chi-Square is 0,000 where $<\alpha 0.05$ or Calculate Chi-Square value of 70.870> Chi-Square table 7,815.

Table 1. Omnibus Test Results

\begin{tabular}{llccc}
\hline & Chi-square & df & Sig. \\
\hline \multirow{3}{*}{ Step 1 } & Step & 70.870 & 3 & .000 \\
\cline { 2 - 5 } & Block & 70.870 & 3 & .000 \\
\cline { 2 - 5 } & Model & 70.870 & 3 & .000 \\
\hline
\end{tabular}

\section{Pseudo R Square}

To see the ability of the independent variable in explaining the dependent variable, the values of Cox \& Snell R Square and Nagelkerke R Square are used. These values are also called the Pseudo R-Square. The logistic regression test results show that the Nagelkerke R Square Value is 0.908 and Cox \& Snell R Square is 0.681, which indicates that the ability of the independent variable to explain the dependent variable is 0.908 or $90.8 \%$ and there are $100 \%-90.8 \%=9.2 \%$ other factors outside the model that explain the dependent variable.

Table 2. Pseudo R Square Results

\begin{tabular}{cccc}
\hline Step & $\mathbf{- 2}$ Log likelihood & Cox \& Snell R Square & Nagelkerke R Square \\
\hline 1 & $15.080^{\mathrm{a}}$ & .681 & .908 \\
\hline
\end{tabular}

\section{DISCUSSION}

\section{Quality of Life}

The results showed that the majority of respondents' quality of life was in the good category. Quality of life is a term used to measure the well-being of the elderly, which describes how well they feel about themselves and their environment (Kaakinen, Duff, Coehlo, \& Hanson, 2010). A good quality of life is an optimal functional condition so that the elderly can enjoy their old age meaningfully, happily and useful (Ng, Hakimi, Byass, Wilopo, \& Wall, 2010). Quality of life is also often used as an indicator in assessing the success of health services (Kaakinen et al., 2010).

\section{Hope}

The hope of the respondents in this study tend to be in the good category. Hope are a combination of abilities and motivation that a person has in creating the chosen strategy to achieve goals (Snyder, 2000). Hope reflect one's perceptions in forming clear conceptual 


\section{STRADA Jurnal Ilmiah Kesehatan}

DOI: $10.30994 /$ sjik.v9i2.519

ISSN: 2252-3847 (print); 2614-350X (online)

Vol.9 No.2 November 2020 Page.1670-1675

goals which can be interpreted as a combination of self-efficacy, intricate motivation, and expectation of results (Linley \& Joseph, 2004). Someone who has hope, tends to enjoy life and vice versa (Olson, 2005).

\section{Friend Support}

The results showed that friend support tended to be in the good category. Friend support is an encouragement or motivation given by friends in helping make decisions (Azwan et al., 2015). Friend support provides benefits for the elderly in dealing with changes in old age. Friend support is formed from emotional attachment, recognition, social integration, reliability, guidance and nurture (Azizah, 2011).

\section{Family support}

Family support in this study tends to be in the good category. Family support is a form of acceptance, attention, appreciation, and comfort obtained from family members, both individuals and groups (Friedman, Bowden, \& Jones, 2010). The elderly tend to feel cared for and appreciated by their existence, which raises joy and motivation in living their old age (Ningrum, Okatiranti, \& Wati, 2017). The presence of a family is considered a very valuable time for the elderly in living their old age (Xu et al., 2019).

\section{Relationship Hope, Friend Support, and Family Support for Quality of Life}

The results of this study indicate that hope, friend support, and family support are able to describe the quality of life of the respondents. This is in line with the following previous studies. Research from Esbensen and Thomsen (2011) on the quality of life and hope in the elderly with cancer shows a significant relationship. Lower quality of life results from low hope. Hope triggers the elderly to increase their adaptive behavior to changing conditions so that they have an impact on their quality of life. Another study from Azwan et al. (2015) showed a relationship between friend social support and the quality of life of the elderly. This is because social support from friends affects the responses and behavior of the elderly so that it affects their quality of life. As well as social support provided by friends will motivate the elderly to do better in carrying out daily activities and the problems they face. Previous research from Ningrum et al. (2017) shows that the level of family support affects the quality of life of the elderly. The higher the family support, the better the quality of life for the elderly. Conversely, the lower the family support causes the quality of life to also decline.

\section{CONCLUSION}

This study shows that the quality of life of the elderly can be explained by hope, support from friends and family support. The results of the study are expected to provide new knowledge for nurses in providing gerontic nursing services to the elderly by increasing hope, friend support, and family support so that it has an impact on the quality of life of the elderly.

\section{ACKNOWLEDGMENTS}

We sincerely thank the Banjar Tengah, Jembrana Regency, Bali for data collection.

This work was financially supported by the Directorate of Research and Community Service, Deputy for Strengthening Research and Development, Ministry of Research and Technology / National Research and Innovation Agency, Republic of Indonesia. 


\section{STRADA Jurnal Ilmiah Kesehatan}

DOI: $10.30994 /$ sjik.v9i2.519

ISSN: 2252-3847 (print); 2614-350X (online)

Vol.9 No.2 November 2020 Page.1670-1675

\section{REFERENCES}

Azizah, L. M. (2011). Keperawatan Lanjut Usia. Yogyakarta: Graha Ilmu.

Azwan, Herlina, \& Karim, D. (2015). Hubungan Dukungan Sosial Teman Sebaya dengan Kualitas Hidup Lansia di Panti Sosial Tresna Werdha. JOM, 2(2), 962-970.

Esbensen, B. A., \& Thomsen, T. (2011). Quality of life and hope in elderly people with cancer. Open Journal of Nursing, 1, 26-32.

Fahmi, A. Z. (2019). Harapan Ditinjau dari Dukungan Sosial pada Remaja Awal. Universitas Islam Indonesia.

Friedman, M. M., Bowden, V. R., \& Jones, E. G. (2010). Buku Ajar Keperawatan Keluarga : Riset, Teori, \& Praktik (5th ed.). Jakarta: EGC.

Herth, K. A. (1989). The relationship between level of hope and level of coping response and other variables in patients with cancer. Oncology Nursing Forum, 16(1), 67-72.

Indrayani, \& Ronoatmodjo, S. (2018). Faktor-Faktor yang Berhubungan dengan Kualitas Hidup Lansia di Desa Cipasung Kabupaten Kuningan Tahun 2017. Jurnal Kesehatan Reproduksi, 9(1), 69-78.

Junovandy, D., Elvinawanty, R., \& Marpaung, W. (2019). Kualitas Hidup ditinjau dari Harapan pada Pasien Wanita Penderita Kanker. Jurnal Ilmiah Psikologi Terapan, 7(1), 41-51.

Kaakinen, J. R., Duff, V. G., Coehlo, D. P., \& Hanson, S. M. M. (2010). Family Health Care Nursing (4th ed.). Philadelphia: FA Davis Company.

Linley, P. A., \& Joseph, S. (2004). Positive Psychology in Practice. New York: Guilford.

Ng, N., Hakimi, M., Byass, P., Wilopo, S., \& Wall, S. (2010). Health and quality of life among older rural people in Purworejo District, Indonesia. Global Health Action, 3(1), 21-25. https://doi.org/10.3402/gha.v3i0.2125

Ningrum, T. P., Okatiranti, \& Wati, D. K. K. (2017). Hubungan Dukungan Keluarga Dengan Kualitas Hidup Lansia (Studi Kasus: Kelurahan Sukamiskin Bandung). Jurnal Keperawatan BSI, 5(2), 83-88.

Olson, K. (2005). Psikologi Harapan. Yogyakarta: Pustaka Pelajar.

Procidano, M. E., \& Heller, K. (1983). Measures of perceived social support from friends and from family: three validation studies. American Journal of Community Psychology, 11(1), 1-24. Retrieved from http://www.embase.com/search/results?subaction=viewrecord \&from=export\&id=L13 674900

Snyder, C. R. (2000). Handbook of Hope Theory, Measures. San Diego: Academic Press.

Souza, A. D., \& Kamble, S. V. (2016). Silver Lining and Hope in Relation with The Quality of Life in Adult Cancer Patients. The International Journal of Indian Psychology, 32(1), 24-31. https://doi.org/10.25215/0302.003

WHO. (2004). The World Health Organization Quality of Life (WHOQOL)-BREF. Retrieved from http://www.who.int/substance_abuse/research_tools/en/indonesian_whoqol.pdf

Xu, D., Mou, H., Gao, J., Zhu, S., Wang, X., Ling, J., \& Wang, K. (2019). Quality of life of nursing home residents in mainland China: The role of children and family support. Archives of Gerontology and Geriatrics, 83, 303-308. https://doi.org/10.1016/j.archger.2019.04.009 